\title{
Repair of Bone Cavities in Dog's Mandible Filled with Inorganic Bovine Bone and Bioactive Glass Associated with Platelet Rich Plasma
}

\author{
Ana Paula Farnezi BASSI ${ }^{1}$ \\ Paulo Sérgio Perri de CARVALHO ${ }^{2}$ \\ ${ }^{1}$ Department of Surgery and Integrated Clinic, Araçatuba Dental School, \\ UNESP - Univ. Estadual Paulista, Araçatuba, SP, Brazil \\ ${ }^{2}$ Department of Surgery and Integrated Clinic, Araçatuba Dental School, UNESP - Univ. Estadual Paulista, Araçatuba, \\ SP, Brazil; Department of Oral Diagnosis, Bauru Dental School, USP - University of São Paulo, Bauru, SP Brazil
}

\begin{abstract}
The aim of this study was to evaluate the effect of platelet rich plasma (PRP) associated to bovine inorganic bone (Bio-Oss ${ }^{\circledR}$; Geistlich) or bioactive glass (Bio-Gran ${ }^{\mathbb{R}}$; Orthovita, Implant Innovations) on bone healing. Bone cavities were prepared in both sides of the mandible of 4 adult male dogs. The cavities were divided into 4 groups according to the filling material as follows: control, PRP, PRP/Bio-Oss, PRP/Bio-Gran. The animals were sacrificed after 120 days and histological and histomorphometrical analysis was performed. The control group showed $80.6 \%$ of bone formation in the longitudinal sections at $6 \mathrm{~mm}$ depth and $83.7 \%$ at $13 \mathrm{~mm}$ depth. The transverse sections displayed $74.2 \%$ at both 6 and $13 \mathrm{~mm}$ depths. The PRP group showed $21.1 \%$ of bone formation in the longitudinal sections at $6 \mathrm{~mm}$ depth, and $23.1 \%$ at $13 \mathrm{~mm}$ depth. The transverse sections presented $28.98 \%$ of bone formation at $6 \mathrm{~mm}$ depth and $41.2 \%$ at $13 \mathrm{~mm}$ depth. The PRP/Bio-Gran group showed $25.1 \%$ of bone formation in the longitudinal sections at $6 \mathrm{~mm}$ depth and $30.4 \%$ at $13 \mathrm{~mm}$ depth. In the transverse sections, the bone formation was $43.0 \%$ at $6 \mathrm{~mm}$ depth and $39.7 \%$ at $13 \mathrm{~mm}$ depth. The PRP/BioOss group showed $35.5 \%$ of bone formation in the longitudinal sections at $6 \mathrm{~mm}$ depth and $42 \%$ at $13 \mathrm{~mm}$ depth. In the transversal sections, the bone formation was $26.8 \%$ and $31.2 \%$ at the depths of 6 and $13 \mathrm{~mm}$, respectively. PRP alone or associated with bovine inorganic bone or bioglass had no significant effect in bone healing.
\end{abstract}

Key Words: platelet rich plasma, inorganic bovine bone, bioactive glass.

\section{INTRODUCTION}

Reconstruction of bone defects is based on the use of autogenous bone graft, either free or vascularized. Autogenous bone graft intends to reestablish the morphofunctional characteristics of the affected areas. The highly osteogenic, osteoconductive and osteoinductive properties lead to a high-quality newly formed tissue (1$3)$. However, the use of autogenous bone grafts requires an additional surgical approach.

Some alternative materials may be used to reduce the morbidity. Natural hydroxyapatite containing inorganic bovine bone matrix and calcium carbonate crystals is commercially available. It does not trigger an immunological reaction and is highly osteoconductive, which allows bone repair (4). It may be used either alone or in combination with autogenous grafts $(5,6)$. It may be applied in isolated lesions, periodontal defects, dehiscences and fenestrations in implants and small osteotomies of the maxillary sinus (2).

Bioactive glass ceramic presents osteoinductive properties (2). It is composed of $45 \%$ silica oxide, $25.5 \%$ calcium oxide, $24.5 \%$ sodium oxide and $6 \%$ phosphate oxide. The size of granules range from 300 to $355 \mu \mathrm{m}^{3}$. This material is hydrophilic and slightly hemostatic and can be placed in the area of the bone defect even in the presence of bleeding. When moistened with sterile saline or patient's blood, a cohesive mass is achieved and may be adapted to fill the bone defect. Eventually, the material is absorbed and replaced by new bone (7).

More recent studies have provided a new option for the treatment of bone defects: platelet rich plasma (PRP). When associated with autogenous bone grafts, homogeneous, heterogeneous or alloplastic implants, it 
may be helpful in more complex clinical situations $(8,9)$.

The gel extracted from the autogenous PRP has been considered a natural membrane, since it allows better adaptation of bone grafts and accelerates bone repair $(2,3)$. It is indicated for correction of bone defects in maxillofacial surgeries and implantology. The main advantages of PRP are: the absence of tissue toxicity, possibility of achievement of a gel within minutes, resorption in few days, and ability to promote repair of bone defects and soft tissue, being easy to achieve. It is an autogenous material, which eliminates the possibility of rejection by the receptor organism $(4,10)$.

This study investigated histologically and histomorphometrically the repair in bone cavities created in mandibles of dogs and filled with PRP or PRP associated to inorganic bovine bone or to bioactive glass.

\section{MATERIAL AND METHODS}

The study protocol was approved by the Committee for Ethics in Animal Experimentation of the Araçatuba Dental School, UNESP Brazil.

The study was performed on 4 male young adult mongrel dogs of similar size and weight, ranging from 10 to $12 \mathrm{~kg}$. The animals were supplied by the Animal Laboratory of the Botucatu Medical School, UNESP, Brazil. All animals were submitted to routine clinical examinations adopted by the Animal Laboratory before the experimental procedures, including platelet counting to assure that all individuals had similar platelet levels. The animals were kept with standard diet comprising solid food, before and throughout the study, except for the preoperative period.

Before the surgical procedures, the animals received $1 \mathrm{~mL}$ of xylazine hydrochloride (Rompun; Bayer do Brasil S/A, São Paulo, SP, Brazil) as a pre-anesthetic drug and sodium pentobarbital as an anesthetic drug by intravenous injection $(33 \mathrm{mg} / \mathrm{kg}$ ), and permeable venoclysis was maintained. During surgery, the animals were restrained by their limbs on the surgical table, in dorsal horizontal decubitus. Tracheotomy was performed, followed by antisepsis with iodine polyvinylpyrrolidone (PVP-I). Sterile drapes were used to keep the surgical field aseptic.

\section{Technique for Obtaining PRP}

Twenty milliliter of autogenous full blood was collected from the femoral vein with a peripheral venous catheter. The blood was placed in hemogram tubes containing anticoagulant (3.8\% sodium citrate), which were centrifuged at $1200 \mathrm{rpm}$ for 8 to $10 \mathrm{~min}$, until separation of the blood elements into 3 layers. The upper fibrogen layer, 40 to $45 \%$ of the total volume, was considered as platelet poor plasma (PPP). The intermediate layer, 30 to $35 \%$ of the total volume, was considered plasma with medium concentration of platelets. The lower and most dense layer, represented 15 to $20 \%$ of the total volume and was considered as PRP. Pipetting was performed in each fraction. Ten percent calcium chloride $(40 \mu \mathrm{L} / \mathrm{mL})$ was added to the PRP for formation of an autogenous PRP gel. The PRP gel was kept at $37^{\circ} \mathrm{C}$ and used after a maximum interval of $1 \mathrm{~h}$. A mean value of peripheral blood platelet counts yielded 148,520 platelets $/ \mu \mathrm{L}$ and the platelet count of PRP was 460,350 platelets $/ \mu \mathrm{L}$ according to the Casati et al. (11).

\section{Surgical Procedure}

After initial preparation, surgery was performed. A straight approximately $5 \mathrm{~cm}$ wide incision was performed on the mandibular base. Dissection and division were performed by planes up to the periosteum. With the surgical field exposed, monocortical bone cavities was prepared using 5-mm trephine burs under thorough irrigation with saline.

Four cavities were prepared in each hemimandible approximately $0.5 \mathrm{~cm}$ far from each other. The cavities were divided into 4 groups: Group I: PRP gel and inorganic bovine bone (Bio-Oss ${ }^{\circledR}$; Geistlich, Wolhusen, Switzerland), Group II: PRP gel and bioactive glass (Bio-Gran ${ }^{\circledR}$; Orthovita, Implant Innovations, Palm Beach Gardens, FL, USA), Group III: PRP gel and blood clot and Group IV: control, only with blood clot. The cavities with their respective materials were covered by a bovine cortical bone membrane and the fascia and skin were closed in separate layers using resorbable sutures.

During the postoperative period, the animals received injectable benzathine penicillin 50,000 IU, intramuscular diclofenac sodium $75 \mathrm{mg}$ ( 1 dose every $12 \mathrm{~h}$ for 2 days), and dipyrone ( $2 \mathrm{cc}$ by intramuscular injection every $6 \mathrm{~h}$ for 1 day). Solid food was maintained.

The animals were euthanized 120 days after surgery by anesthetic overdose and the mandible fragments were removed, fixed in $10 \%$ formalin and decalcified in 20\% EDTA solution for 60 days. After decalcification, specimens were obtained in two directions, sagittal and transverse. Histological and histometric 
analyses were performed on 6- $\mu \mathrm{m}$ thick sections mounted on glass slabs and stained with hematoxylin and eosin.

Histological analysis was performed by light microscopy. For histometric analysis, the images were captured by a digital camera connected to the light microscope using the software Videocap and were analyzed with Imagelab 2000 software (Diracon Bio. Informática Ltda., Vargem Grande do Sul, SP, Brazil). The areas of new bone formation, connective tissue and biomaterial were quantified in percentage. The values of each group were tabulated for statistical quantification.

\section{Statistical Analysis}

Statistical analysis comprised ANOVA in subdivided parts (split-plot) for the values achieved in new bone formation, in order to verify whether there was difference between groups and the interactions between groups and sections. Statistical analysis was complemented by the Tukey's test at a significance level of $5 \%$. Analysis of the transverse sections comprised removal of the values achieved for dog 1 , since its values were analyzed only for groups PRP and PRP/bioactive glass, and outlier data were achieved compared to the other groups. All analyses were performed using the SAS software (SAS Institute Inc., Cary, NC, USA).

\section{RESULTS}

\section{HISTOLOGICAL RESULTS}

The results were obtained from longitudinal and

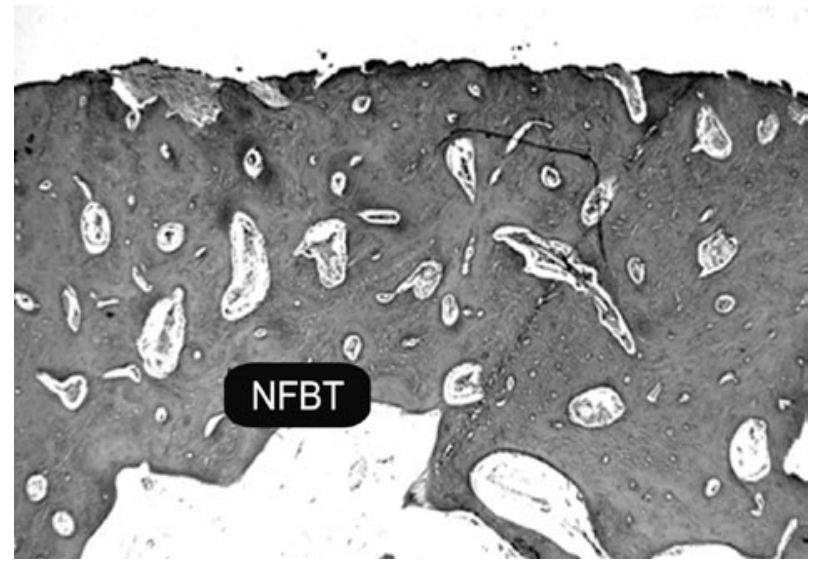

Figure 1. Newly formed bone tissue (NFBT) presenting wide intertrabecular spaces characterizing tissue in maturation stage. H.E. $25 \times$ original magnification. transverse sections of the bone cavities at 120 days postoperatively.

\section{Control Group}

The bone cavities were nearly entirely filled with bone tissue, reconstructing the cortical plate. The central portion of the surgical wound presented a small area with connective tissue without bone differentiation. When compared to the preexisting bone tissue, the newly formed bone tissue still presented wide intertrabecular spaces, characterizing a tissue in maturation stage. Some specimens exhibited centripetal repair of the bone cavity, i.e. from the laterals toward the center. In these cases, the central portion of the surgical wound was filled with connective tissue rich in collagen fibers. The deepest region presented a fibrin network, suggesting occurrence of hemorrhage and probable displacement of the blood clot. The bone tissue followed the same pattern of repair in all specimens (Figs. 1 and 2).

\section{PRP Group}

All specimens revealed presence of connective tissue at the center of the bone cavity, suggesting a central bone defect. The repair process occurred along the entire cavity, from the lateral walls to the central portion of the surgical wound. The fibrin network was visible below the connective tissue. The new bone formation at the surface region of the cavity was characterized by bone tissue with presence of osteocytes and wide medullary spaces indicating osteoactivity (Fig. 3).

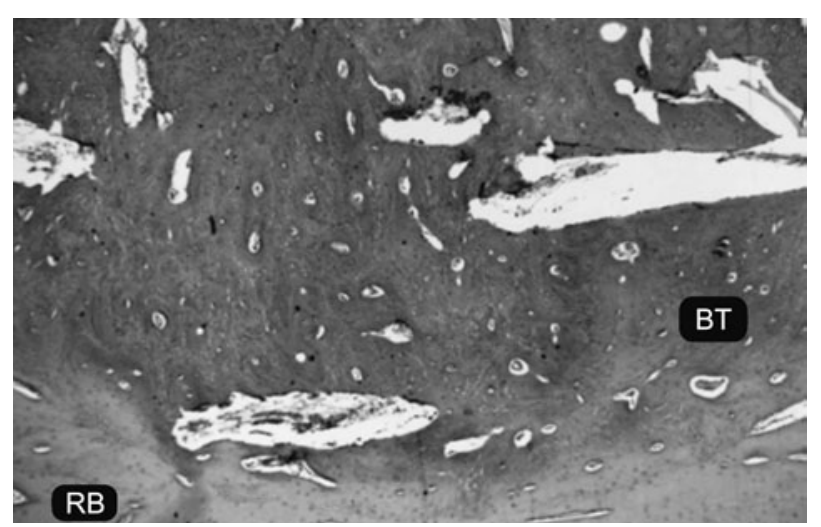

Figure 2. Image of bone cavity well delimited by the remaining bone (RM), characterized by mature bone tissue (BT) and reduced intertrabecular spaces with concentric formation. H.E. $25 \times$ original magnification. 


\section{Bioactive Glass Group}

The cavity margin exhibited wide trabecular spaces, revealing newly formed bone tissue. There were spaces partially filled by non-mineralized tissue and undifferentiated connective tissue. Towards the center of these cavities there was tissue with aspect of newly formed bone, suggesting new bone formation around the bioactive glass granules. The center of the cavity revealed a great amount of Bio-Gran ${ }^{\circledR}$ granules. All these granules were surrounded by connective tissue in differentiation (with few cells or rich in collagen fibers). In some areas this tissue had aspect of newly formed bone. All granules were surrounded by connective tissue rich in collagen fibers and non-mineralized tissue. The cavities did not present a cortical plate on their surface (Fig. 4).

\section{Inorganic Bovine Bone Group}

The cavity margin exhibited newly formed bone tissue and incorporation of part of the material granules. There were spaces partially filled with non-mineralized tissue and undifferentiated connective tissue, similar to the bioactive glass group, even though the presence of non-mineralized tissue was observed in smaller amount in this group. Towards the center of these cavities there was tissue with aspect of newly formed bone, suggesting new bone formation around the inorganic bovine bone granules. The center of the cavity revealed a great amount of inorganic bovine bone granules surrounded by connective tissue in differentiation, yet with a smaller degree of differentiation than the bioactive glass group. The cavities did not present a cortical plate on their surface. A higher magnification in the microscope

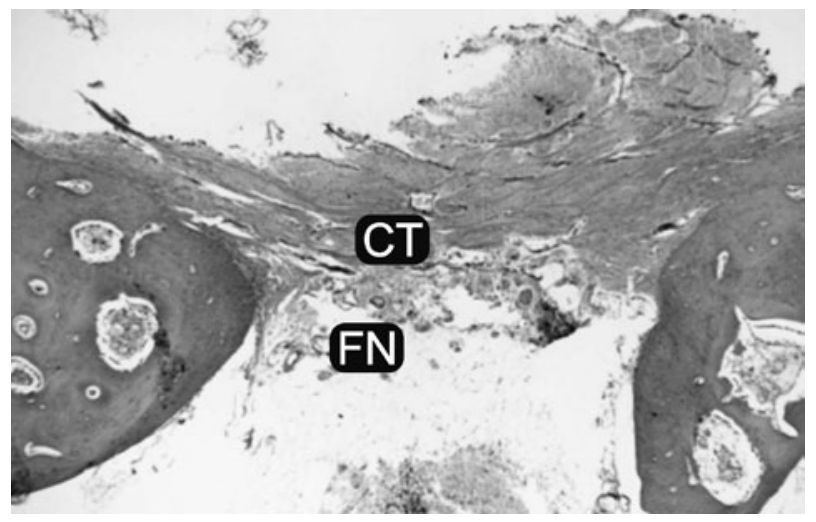

Figure 3. Photomicrograph exhibiting connective tissue (CT) and fibrin network (FN). H.E. $25 \times$ original magnification. revealed presence of multinucleated cells close to the inorganic bovine bone particle (Figs. 5 and 6).

\section{HISTOMETRIC RESULTS}

\section{Longitudinal Sections}

There was a significant difference $(p<0.05)$ between the control group and the other groups (PRP/ inorganic bovine bone + PRP/bioactive glass + PRP). Significant differences $(\mathrm{p}<0.05)$ were also observed when the inorganic bovine bone + PRP group and the PRP and bioactive glass + PRP groups were compared. Bioactive glass + PRP and isolated PRP groups did not reveal significant differences $(\mathrm{p}>0.05)$ (Table 1).

The values within groups $(6 \mathrm{~mm}$ - superficial sections and $13 \mathrm{~mm}$ - deep sections) revealed significant differences with proportionality among data $(\mathrm{p}<0.05)$, with occurrence of a linear increase in the amount of new bone formation in deeper sections (Table 1).

\section{Transverse Sections}

Significant differences $(\mathrm{p}<0.05)$ were observed between the control and the other groups (PRP/PRP + inorganic bovine bone/PRP + bioactive glass). However, comparison among the other groups did not reveal significant differences $(\mathrm{p}>0.05)$ (Table 2).

The results were not statistically significant in the comparison within groups (Bioactive glass and PRP), with a slight inversion in proportionality in one group (Control) (Table 2).

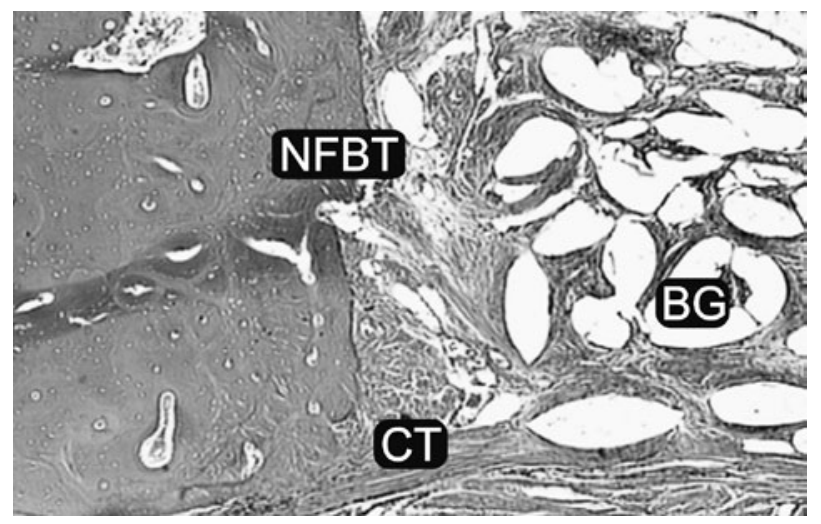

Figure 4. Photomicrograph exhibiting connective tissue (CT) and bioactive glass granules (BG) at the center of the cavity. Presence of newly formed bone tissue at the lateral wall (NFBT). H.E. 50× original magnification. 


\section{DISCUSSION}

In the present study, PRP did not improve new bone formation in bone cavities created in dogs' mandibles. Histometric evaluation, which calculated the percentage of new bone formation, revealed values of $21.1 \%$ at $6 \mathrm{~mm}$ depth and $23.1 \%$ at $13 \mathrm{~mm}$ depth. The transverse sections exhibited $28.98 \%$ at $6 \mathrm{~mm}$ depth and $41.2 \%$ at $13 \mathrm{~mm}$. Statistically significant differences were $(\mathrm{p}<0.05)$ were found when the PRP group and the control group were compared. The longitudinal sections of specimens in the control group exhibited $80.6 \%$ of new bone formation at $6 \mathrm{~mm}$ depth and $83.7 \%$ at 13 $\mathrm{mm}$ depth. The transverse sections displayed $74.2 \%$ of

Table 1. Longitudinal data (mean and standard error of the mean).

\begin{tabular}{lccc}
\hline & \multicolumn{2}{c}{ Newly formed bone (\%) } & \\
\cline { 2 - 3 } Group & $\begin{array}{c}\text { 6-mm-thick } \\
\text { section }\end{array}$ & $\begin{array}{c}\text { 13-mm-thick } \\
\text { section }\end{array}$ & Total \\
\hline PRP & $21.1 \pm 1.7$ & $23.1 \pm 1.6$ & $22.1 \pm 1.2^{\mathrm{c}}$ \\
Bioactive glass & $25.1 \pm 1.7$ & $30.4 \pm 1.3$ & $27.8 \pm 1.2^{\mathrm{c}}$ \\
$\begin{array}{l}\text { Inorganic } \\
\text { bovine bone }\end{array}$ & $35.5 \pm 2.6$ & $42.0 \pm 3.8$ & $38.8 \pm 2.3^{\mathrm{b}}$ \\
Control & $80.6 \pm 2.7$ & $83.7 \pm 2.0$ & $82.1 \pm 1.7^{\mathrm{a}}$ \\
Total & $40.6 \pm 3.4^{\mathrm{B}}$ & $44.8 \pm 3.4^{\mathrm{A}}$ & \\
\hline
\end{tabular}

$\mathrm{PRP}=$ Platelet-rich plasma. Means followed by same lowercase letters in columns and uppercase letters in rows are not different from each other (Tukey's test; $\mathrm{p}<0.05$ ).

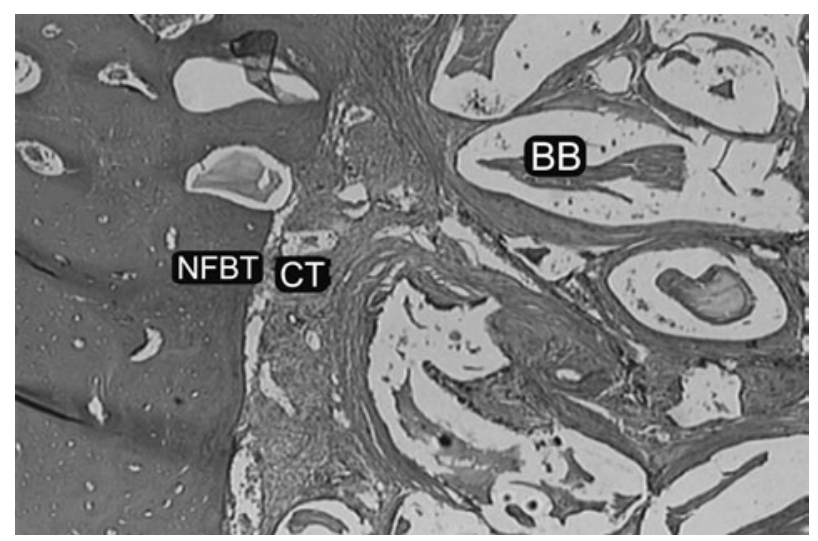

Figure 5. Section exhibiting connective tissue (CT), inorganic bovine bone granules (BB) at the center of the cavity. Presence of newly formed bone tissue (NFBT) at the periphery. H.E. 50× original magnification. new bone formation at both $6 \mathrm{~mm}$ and $13 \mathrm{~mm}$ depth.

Aghaloo et al. (12) investigated cranial vault defects in rabbits and concluded that, even though it did not impair the repair process, the PRP did not improve the new bone formation when compared to the control group. The results revealed significant interference when the defects were filled with autogenous bone associated or not to PRP, suggesting that the important factor was the presence of autogenous bone rather than the PRP This result suggests that to achieve an effect PRP it requires a "framework" to keep it in the surgical site.

It should be considered that platelets release growth factors immediately at the area, which work only for a period of 7 to 10 days (8). Perhaps for this

Table 2. Transverse data (mean and standard error of the mean).

\begin{tabular}{lccc}
\hline & \multicolumn{2}{c}{ Newly formed bone (\%) } & \\
\cline { 2 - 3 } Group & $\begin{array}{c}\text { 6-mm-thick } \\
\text { section }\end{array}$ & $\begin{array}{c}\text { 13-mm- } \\
\text { thick section }\end{array}$ & \\
\hline PRP & $19.3 \pm 3.2$ & $24.2 \pm 3.8$ & $21, .7 \pm 2.5^{\mathrm{b}}$ \\
Bioactive glass & $32.1 \pm 7.13$ & $28.4 \pm 4.7$ & $30.3 \pm 4.1^{\mathrm{b}}$ \\
$\begin{array}{l}\text { Inorganic } \\
\text { bovine bone }\end{array}$ & $26.8 \pm 0.9$ & $31.2 \pm 1.5$ & $29.0 \pm 1.0^{\mathrm{b}}$ \\
Control & $74.2 \pm 4.3$ & $73.9 \pm 4.0$ & $74.0 \pm 2.8^{\mathrm{a}}$ \\
Total & $39.9 \pm 4.7^{\mathrm{A}}$ & $41.3 \pm 4.3^{\mathrm{A}}$ & \\
\hline
\end{tabular}

$\mathrm{PRP}=$ Platelet-rich plasma. Means followed by same lowercase letters in columns and uppercase letters in tows are not different from each other(Tukey's test; $\mathrm{p}<0.05$ ).

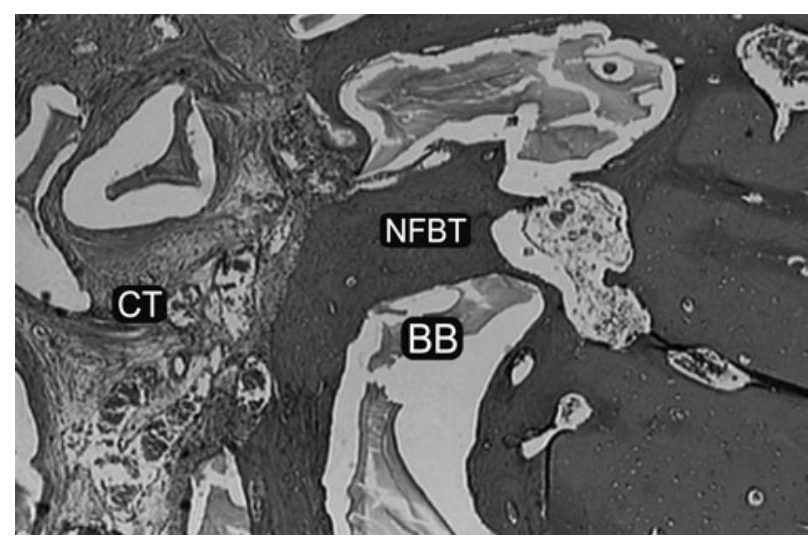

Figure 6. Section exhibiting connective tissue (CT), inorganic bovine bone granules (BB) at the center of the cavity. Presence of newly formed bone tissue (NFBT) at the periphery surrounding the inorganic bovine bone granule. H.E. 50× original magnification. 
reason some authors have found a better result of PRP at the initial periods, with no differences at completion of the repair process, as in the study by Zechner et al. (13) in pigs' alveolus. According to the Merck \& Co Veterinary manual (14), there is a great variation in the baseline values of the platelet numbers within and between species. Mooren et al. (15) reported that this variation in the concentration of the platelets may play an important role in the conflicting results reported in various animal experimental studies using PRP.

In the present study, the use of bioactive glass associated with PRP demonstrated a percentage of new bone formation in longitudinal sections of $25.1 \%$ at 6 mm depth and $30.4 \%$ at $13 \mathrm{~mm}$ depth. In the transverse sections, the mean was $43.0 \%$ at $6 \mathrm{~mm}$ depth and $39.7 \%$ at $13 \mathrm{~mm}$, significantly less $(\mathrm{p}<0.05)$ than in the control group. When compared to the PRP group, despite the lack of statistical significance, histologically it could be observed that association of PRP to bioactive glass was more effective compared to its use alone. Histological analysis revealed that complete repair of the cavities was not achieved in any specimen.

One of the remarkable characteristics of this study was the presence of a large amount of nonmineralized tissue at both the center of cavities and bioactive glass granules. This tissue did not present specific characteristics of connective tissue nor bone tissue, suggesting that a great part of this tissue may be differentiated into bone tissue. It was also observed that part of the granules was surrounded by newly formed bone tissue, corroborating previous $(1,16,17)$.

The other material analyzed was the inorganic bovine bone. In longitudinal sections, a mean bone formation of $35.5 \%$ at $6 \mathrm{~mm}$ depth and $42 \%$ at $13 \mathrm{~mm}$ were observed. In the transverse sections the values were $26.8 \%$ and $31.2 \%$ at depths of $6 \mathrm{~mm}$ and $13 \mathrm{~mm}$, respectively. The differences were significant $(p<0.05)$ when compared to the control group. When compared to the PRP group, the differences were significant $(p>0.05)$ in longitudinal sections, which is in agreement with the morphological analysis. The differences were not significant in the transverse sections. Even though complete filling of the bone cavities was not achieved in any situation, it was possible to verify that the group treated by association of inorganic bovine bone and PRP displayed greater bone formation compared to the isolated use of PRP.

Some studies have been published on the association of inorganic bovine bone and PRP.
Froum et al. (18), in the report of 3 cases, verified by histomorphometric analysis that the association of these 2 materials did not yield significant differences compared to the vital bone. Kassolis et al. (19) demonstrated that, histologically, this association allows formation of several osteoid areas and bone formation around the granules, yet it was not better than the results obtained in cavities in which only the blood clot was left.

When inorganic bovine bone group was compared to the bioactive glass group, longitudinal histomorphometric analysis revealed that the inorganic bovine bone achieved a higher percentage of new bone formation. However, the new bone formation in the transverse histomorphometric analysis was slightly superior in the bioactive glass group. Morphological analysis revealed that the bioactive glass group exhibited a larger amount of non-mineralized tissue and a smaller amount of fibrous connective tissue then the inorganic bovine bone group. This non-mineralized tissue is believed to have the potential to undergo maturation. Even though the inorganic bovine bone group exhibited numerically larger new bone formation (longitudinal sections, significant difference), the bioactive glass group is believed to have a greater potential to complete new bone formation of cavities, despite the need of a longer time for that.

This way, whereas part of the literature believes that the association of PRP and autogenous bone is encouraging $(3,8)$, other studies have indicated that PRP associated to bone substitutes is effective (12). Under the tested conditions, the results suggest that PRP is not advantageous in the repair of bone cavities in dogs' mandibles, when used alone or associated with bioactive glass or inorganic bovine bone. There was no quantitative or qualitative improvement in bone when compared to the control group. Further studies are required to better define the effects of PRP in the process of bone repair.

\section{RESUMO}

O objetivo deste trabalho foi avaliar os efeitos do PRP associado ao osso bovino inorgânico ou vidro bioativo no processo de reparo ósseo. Foram utilizados 4 cães adultos, onde foram preparadas cavidades ósseas em região mandibular dos dois lados. As cavidades foram divididas em 4 grupos de acordo com o material utilizado: controle, PRP, PRP/Bio-Oss ${ }^{\circledR}, \mathrm{PRP} / \mathrm{Bio}-\mathrm{Gran}^{\circledR}$. O sacrifício dos animais foi realizado 120 dias depois do procedimento cirúrgico e análises histológicas e histomorfométricas foram realizadas. O grupo controle demonstrou $80,6 \%$ de formação óssea no corte longitudinal com profundidade de $6 \mathrm{~mm}$ e $83,7 \%$ no corte longitudinal com profundidade de $13 \mathrm{~mm}$. Nos cortes 
transversais de 6 e $13 \mathrm{~mm}$ de profundidade mostrou $74,2 \%$ de formação óssea. O grupo PRP demonstrou 21,1\% de formação óssea no corte longitudinal com profundidade de $6 \mathrm{~mm}$ e $23,1 \%$ no corte longitudinal com profundidade de $13 \mathrm{~mm}$. Nos cortes transversais de $6 \mathrm{~mm}$ de profundidade mostrou $28,98 \%$ e $41,2 \%$ nos de $13 \mathrm{~mm}$. O grupo PRP/bio-Gran ${ }^{\circledR}$ demonstrou 25,1\% de formação óssea no corte longitudinal com profundidade de $6 \mathrm{~mm}$ e $30,4 \%$ no corte longitudinal com profundidade de $13 \mathrm{~mm}$. Nos cortes transversais de $6 \mathrm{~mm}$ de profundidade mostrou $43,0 \%$ de formação óssea e 39,7\% nos de 13 mm. Para o grupo PRP/Bio$\mathrm{Oss}^{\circledR}$ nos cortes longitudinais obtivemos $35,5 \%$ para os cortes de $6 \mathrm{~mm}$ e $42 \%$ para os $13 \mathrm{~mm}$. Nos cortes transversais a formação óssea encontrada foi de $26,8 \%$ e $31,2 \%$ paras as profundidades de 6 e $13 \mathrm{~mm}$ respectivamente. Conclui-se que o uso isolado associado do PRP com o osso bovino inorgânico ou vidro bioativo não possui um efeito significativo no processo de reparo ósseo.

\section{REFERENCES}

1. Froum S, Wallace SS, Tamow DP, Cho SC. Effect of plateletrich plasma on bone growth and osseointegration in human maxillary sinus grafts: three bilateral case reports. Int Periodontics Restorative Dent 2002;22:45-53.

2. Lynch SE, Genco RJ, Marx RE. Tissue engineering: Applications in maxillo-facial surgery and periodontics. Carol Stream: Quintessence Books, 1999.

3. Marx RE, Wong ME. A techinique for the compression and carriage of autogenous bone during bone grafting procedures. J Oral Maxillofac Surg 1987;45:988-989.

4. Hannon T, Pekarske W. Preparation of autologous patelet gel, 1997.

5. Hislop WS, Finlay PM, Moos KP. A preliminary study into the uses of anorganic bone in oral and maxillofacial surgery. Br J Oral Maxillofac Surg 1993;31:149-153.

6. Schepers EJG, Ducheyne P, Barbier L, Schepers S. Bioactive glass particles of narrow size range: a new material for repair of bone defects. Implant Dent 1993;2:151-156.

7. Schepers EJG, Ducheyne P. Bioactive glass particles of narrow size range for the treatment of oral bone defects: a 1-24 month experiment with several materials and particle sizes and size ranges. J Oral Rehabil 1997;4:71-81.

8. Marx RE, Carlson ER, Eichstaedt RM, Schimmele SR, Strauss JE, Georgeff KR. Platelet-rich plasma. Growth factor enhancement for bone grafts. Oral Surg Oral Med Oral Patho Oral Radiol Endod 1998;85:638-646.

9. Marx RE. Platelet-rich plasma: evidence to support its use. J Oral Maxillofac Surg 2004;62:489-496.

10. Mooren RECM, Merkx MAW, Bronkhorst EM, Jansen JA, Stoelinga PJW. The effect of platelet-rich plasma on early and late bone healing: an experimental study in goats. Int J Oral Maxillofac Surg 2007;36:626-631.

11. Casati MZ, Vasconcelos Gurgel BC, Gonçallves PF, Pimentel SP, Rocha G, Nogueira Filho, et al.. A. Platelet-rich plasma does not improve bone regeneration around peri-implant bone defects - a pilot study in dogs. Int J Oral Maxillofac Surg 2007;36:132-136.

12. Aghaloo TL, Moy PK, Freymiller EG. Investigation of plateletrich plasma in rabbit cranial defects: a pilot study. J Oral Maxillofac Surg 2002;60:1176-1181.

13. Zechner W, Tangl S, Tepper G, Fürst G, Bernhart T, Haas R, et al.. Influence of platelet-rich plasma on osseos healing of dental implants: a histologic and histomorphometric study in minipigs. Int J Maxillofac Implants 2003;18: 5-22.

14. Merck. 2006. The Merck Veterinary Manual. Merck \& Co., Inc. Table 6 Hematologic Reference Ranges. Available from: http:// www.merckvetmanual.com/mvm/index.jsp?cfile $=$ htm/bc/ref_00. htm. February 10, 2006. Latest access on March 12, 2011.

15. Mooren REC, Dankers ACA, Merks MAW, Bronkhorst EM, Jansen JA, et al.. The effect of platelet-rich plasma on early and late bone healing using a mixture of particulate autogenous cancellous bone and Bio-Oss ${ }^{\circledR}$ an experimental study in goats. Int J Oral Maxillofac Surg 2010;39:371-378.

16. Furusawa T, Mizunuma K. Propiedades osteoconductivas y eficacia del cristal bioactivo reabsorbible como material de injerto óseo. Impl Dent 1997;3:14-24.

17. Johnson MW, Sullivan SM, Rohrer M, Collier M. Regeneration of peri-implant infrabony efects using perioglass: a pilot study in rabbits. Int J Oral Maxillofac Implants 1997;12:835-839.

18. Froum S, Cho SC, Rosenberg E, Rohrer M, Tamow D. Histological comparison of healing extraction sockets implanted with bioative glass or demineralized freeze-dried bone allograft: a pilot study. J Periodontol 2002;73:94-102.

19. Kassolis JD, Rosen PS, Reynolds MA. Alveolar ridge and sinus augmentation utilizing platelet-rich plasma in combination with freeze-dried bone allograft: case series. J Periodontol 2000;71:1654-1661. 